\title{
Meningkatkan Kemampuan Pedagogi Guru Dalam Membuat Soal Ulangan Online Melalui Pelatihan di SMP Negeri 38 Takengon Tahun Ajaran 2020/2021
}

\author{
Syukriamsyah \\ SMP Negeri 38 Takengon \\ Email. Syukriamsyah84@gmail.com
}

\begin{abstract}
Abstrak
Penelitian ini berjudul "Meningkatkan Kemampuan Pedagogi Guru Dalam Membuat Soal Ulangan Online Melalui Pelatihan di SMP Negeri 38 Takengon Tahun Ajaran 2020/2021". Melaksanakan penilaian merupakan suatu kewajiban bagi guru di SMP Negeri 38 Takengon pada saat masa pandemik covid-19, dimana sistem penilaian berubah dari ulangan berbasis tulis kertas menjadi ulangan online. Untuk melancarkan sistem ulangan online kepala sekolah membuat pelatihan sederhana yaitu melalui pelatihan luring yang dilaksankan di sekolah. Penelitian ini menggunakan metode deskriptif kualitatif. Teknik pengumpulan data dengan cara wawancara, observasi, dan dokumentasi. Data yang diperoleh kemudian dianalisis menggunakan model analisis suharsimi Arikunto untuk selanjutnya diperoleh kesimpulan. Hasil penelitian pada penelitian ini ada peningkatan dari siklus 1 ke siklus 2 sebesar $(17,69)$ pada siklus 1 nilai rata-rata guru adalah $(60,44)$, sementara pada siklus 2 meningkat menjadi $(78,13)$ artinya ada peningkatan yang signifikan secara kelasikal pada guru di SMP Negeri 38 Takengon. Penelitian dikatakan berhasil apabila ada peningkatan dari siklus 1 ke siklus 2. Kesimpulan hasil penelitian yaitu adanya peningkatan nilai kemampuan pedagogik guru dalam membuat soal ulangan online berbasis google form dalam menghadapi ulangan dimasa pandemik covid-19 serta penerapanya pada guru di SMP Negeri 38 Takengon tahun ajaran 2020/2021.
\end{abstract}

\section{Kata Kunci: Pelatihan, Ulangan Online, Google Form}

\section{PENDAHULUAN}

Sekolah Menengah Pertama Negeri 38 Takengon, merupakan lembaga yang didirikan oleh pemerintah untuk tempat proses belajar mengajar, yang bertujuan untuk mencerdaskan anak bangsa dimana sesuai dengan tujuan pemerintah anak wajib belajar sembilan tahun. Sekolah merupakan suatu hal yang sangat penting untuk kehidupan manusia dengan tidak adanya sekolah, maka kualitas pendidikan masyarakat yang ada di Indonesia umunya, khusunya daerah kami yaitu Aceh Tengah jadi terganggu. Kehidupan yang dijalanipun juga tidak akan terjamin, banyak terjadinya pengangguran dimana-mana sebab ilmu yang dimiliki tidak mampu untuk memenuhi standar yang diinginkan. Untuk itu, pendidikan itu sangat penting bagi kita sebagai generasi penerus bangsa. Peran orang tua sangat penting sebagai dorongan bagi anak-anaknya untuk tetap terus semangat dalam menempuh pendidikan sekolah. Peran orang tua sebagai pendidik sejati sementara digantikan dan diserahkan sepenuhnya kepada tenaga pendidik yang lebih profesional dalam hal bidangnya.

Seseorang dianggap telah belajar sesuatu jika dia dapat menunjukkan perubahan perilakunya. Menurut teori ini, dalam belajar yang paling penting adalah adanya input 
yang berupa stimulus serta adanya output yang berupa respons yang ditimbulkan. Dengan kata lain, definisi belajar secara singkat adalah upaya dan berusaha untuk memperoleh kepandaian atau ilmu, berlatih, berubah tingkah laku atau tanggapan yang disebabkan oleh pengalaman. Kegiatan belajar bisa dilakukan di mana saja, misalnya di sekolah, di rumah, dan di tempat lain seperti di museum, di laboratorium, di hutan dan lain-lain. Setiap dari proses pembelajaran tentu guru sangat mengharapkan hasil proses belajarnya siswa baik pekerjaan rumah, ulangan harian maupun Penilaian Tengah Semester (PTS) dan Ulangan Semester (US) yang rutin setiap tahun dilaksankan di setiap sekolah.

Ulangan yang dilaksanakan atau dilakukan disetiap sekolah oleh guru bertujuan untuk mengukur kemampuan dari hasil proses belajar mengajar siswa. Ulangan dapat dilakukan dengan cara yang beragam bisa dengan lisan maupun tulisan. (Permendikbud No.66 Tahun 2013 tentang Standar Penilaian Pendidikan). Penilaian tengah semester : merupakan kegiatan yang dilakukan oleh pendidik untuk mengukur pencapaian kompetensi peserta didik setelah melaksanakan 8-9 minggu kegiatan pembelajaran. Cakupan ulangan tengah semester meliputi seluruh indikator yang merepresentasikan seluruh kompetensi dasar pada periode tersebut. Ulangan yang selama ini dilaksanakan di SMP Negeri 38 Takengon, dilaksanakan berbasis ujian tulis kertas atau manual yang memiliki beberapa kelemahan, ketidak seriusan siswa dalam ujian, menganggap ujian hanya sebagai formalitas, pemborosan terhadap kertas, bahkan tidak mengenalkan hal yang positif terhadap siswa dalam menggunakan android maupun komputer sebagai media ajar.

Handphone yang sistem operasionalnya menggunakan Android. Sistem operasi Android menjadi pilihan bagi vendor-vendor smart phone karena memiliki biaya lisensi lebih murah dan sifatnya yang semi opensource. Tidak hanya itu Android tentunya akan support dengan berbagai layanan dari Google. Berdasarkan keterangan pengertian android di atas aplikasi yang terdapat didalamnya tersebut telah terprogram yaitu aplikasi google, hal ini tentu sangat memudahkan semua orang untuk memanfaatkan atau melakukan pengembangan sesuai dengan yang dinginkan. Berdasarkan observasi dan hasil wawancara yang saya lakukan di SMP Negeri 38 Takengon, dengan jumlah sebanyak 16 orang guru. Hasil observasi $100 \%$ guru masih membuat soal menggunakan kertas yang intinya semua guru belum mampu memanfaatkan teknologi sesuai harapan pembelajaran abad 21. Google saat ini terus melakukan inovasi dari berbagai platform yang dimilikinya, di antaranya google docs, yang salah satu fiturnya turut menghadirkan Google form. Biasanya digunakan untuk beberapa hal seperti memebuat kuisioner, membuat quick count pendapat, membuat fomulir pendaftaan online, kemudian mengelolanya dan masih banyak lagi.

Untuk mengatasi permasalahn diatas saya selaku kepala di SMP Negeri 38 Takengon, akan membuat pelatihan yang bertujuan untuk meningkatkan kemampuan guru dalam membuat soal ulangan online berbasis google Form, pelatihan yang dimaksud adalah kegiatan yang dirancang untuk mengembangkan kemampuan pedagogic guru melalui rangkaian kegiatan identifikasi, pengkajian serta proses belajar yang terencana. Hal ini dilakukan melalui upaya untuk membantu mengembangkan kemampuan yang diperlukan agar dapat melaksanakan tugas, baik sekarang maupun di masa yang akan datang. Kegiatan pelatihan adalah pelatihan yang memanfaatkan aplikasi goggle Form. Google form adalah layanan dari Google yang memungkinkan 
anda untuk membuat survey, tanya jawab dengan fitur formulir online yang bisa dikustomisasi sesuai dengan kebutuhan. Jadi guru bisa mendapatkan jawaban secara langsung dari siswa yang mengikuti ulangan. Adapun manfaat dari kegiatan pelatihan mini adalah guru dapat membuat soal dengan memanfaatkan goggle form, sehingga siswa dapat langsung menjawab soal yang ada di android dan keuntungan bagi guru dapat langsung melihat hasil jawaban siswa secara otomatis pada aplikasi yang direncanakannya.

Berdasarkan permasalah diatas, maka dipandang perlu dilakukan suatu penelitian yang berjudul "Peningkatkan Kemampuan Pedagogik Guru Dalam Membuat Soal Ulangan Online Melalui Pelatihan di SMP Negeri 38 Takengon Kabupaten Aceh Tengah Tahun Ajaran 2020/2021".

\section{Tujuan Penelitian}

Tujuan penelitian ini yaitu mendeskrifsikan peningkatan kemampuan pedagogik guru dalam membuat soal online serta kendala-kendala yang dihadapi oleh siswa pada saat melaksanakan ulangan online berbasis google form tahun ajaran 2020/2021 di SMP Negeri 38 Takengon.

\section{LANDASAN TEORITIS \\ Pengertian Belajar}

Sudjana (2010) : Belajar adalah suatu proses yang ditandai dengan adanya perubahan pada diri seseorang. Perubahan hasil proses belajar dapat ditunjukkan dalam berbagai bentuk seperti penambahan pengetahuan, pemahaman, sikap dan tingkah laku, kecakapan, kebiasaan serta perubahan aspek-aspek lain yang ada pada individuindividu yang belajar. Suyono dan Hariyanto (2011) yaitu belajar merupakan suatu aktifitas atau proses untuk memperoleh pengetahuan, meningkatkan keterampilan, memperbaiki perilaku, sikap, dan mengokohkan kepribadian.

\section{Pengertian Ulangan atau Tes}

Ulangan menurut Permendiknas (2006) "yang berkaitan dengan standar pendidikan merupakan suatu proses pencapaian kompetensi peserta didik dengan cara terus-menerus secara berkelanjutan melalui proses pembelajaran yang berguna untuk memantau kemajuan, perbaikan dan menentukan keberhasilan proses keberhasilan peserta didik". Ulangan bisa diartikan sebagai tes, yang dapat mengukur tingkat keberhasilan peserta didik dalam proses pebelajaran. Sebagai tahap pengukuran, ulangan dalam soal Ulangan Akhir Semester yang merupakan titik tolak menukur dalam kemapuan siswa. Alat yang dapat digunakan dalam mengukur sesuatu hal dengan cara aturan yang sudah ditentukan disebut sebagai tes (Arikunto, 2012). Begitu halnya dengan, tes yang merupakan hasil dari proses belajar dengan menggunakan tes penguasaan, karena tes dapat mengukur kemampuan siswa terhadap materi saat diajarkan oleh guru atau bisa juga yang dipelajari sendiri oleh siswa (Puwanto, 2011). Ditambahkan dari teori Majid, tes dijadikan sebagai perangkat atau alat yang didalamnya terdapat soal yang harus dikerjakan oleh siswa untuk mengukur tingkat pemahaman dari siswa (2014). 


\section{Pengertian Pedagogik}

Kompetensi Pedagogik merupakan salah satu jenis kompetensi yang mutlak perlu dikuasai guru. Kompetensi Pedagogik pada dasarnya adalah kemampuan guru dalam mengelola pembelajaran peserta didik. Kompetensi Pedagogik merupakan kompetensi khas, yang akan membedakan guru dengan profesi lainnya dan akan menentukan tingkat keberhasilan proses dan hasil pembelajaran peserta didiknya. Kompetensi ini tidak diperoleh secara tiba-tiba tetapi melalui upaya belajar secara terus menerus dan sistematis, baik pada masa pra jabatan (pendidikan calon guru) maupun selama dalam jabatan, yang didukung oleh bakat, minat dan potensi keguruan lainnya dari masing-masing individu yang bersangkutan. Berkaitan dengan kegiatan Penilaian Kinerja Guru terdapat 7 (tujuh) aspek dan 45 (empat puluh lima) indikator yang berkenaan penguasaan kompetensi pedagogik. Berikut ini disajikan ketujuh aspek kompetensi pedagogik :

1. Menguasai karakteristik peserta didik

2. Menguasasi teori belajar dan prinsip-prinsip pembelajaran yang mendidik

3. Pengembangan kurikulum

4. Kegiatan pembelajaran yang mendidik

5. Pengembangan potensi peserta didik

6. Komunikasi dengan peserta didik

7. Penilaian dan evaluasi

\section{Pengertian Ujian Online}

Menurut Anggraini (2007) secara umum dikatakan online adalah bila ia terkoneksi/terhubung dalam suatu jaringan ataupun sistem yang lebih besar. Menurut tanggapan Arli (2014) secara sederhana, e-learning adalah memindahkan proses belajar-mengajar secara konvensional kepada dunia maya atau internet. Umumnya, aplikasi yang digunakan adalah web-based. Pada sistem E-Learning menggunakan Learning Management System (LMS) Moodle. Sistem tersebut dimuat dihalaman website dengan domain tertentu, sehingga dapat melakukan proses ujian online, penyimpanan nilai dan penilaian hasil pembelajaran secara online. Penilaian hasil ujian online hanya dapat diakses oleh server tentunya yang terkoneksi jaringan internet. Kenneth (2010) mengemukakan bahwa ujian online dapat meningkatkan standar ujian siswa sedangkan system ujian tradisional dengan menggunakan pena dan kertas membutuhkan usaha lebih untuk siswa dan pengawas ujian. Ujian secara manual juga membutuhkan waktu lebih lama karena peserta ujian harus menyiapkan peralatan (buku, pena/pensil, penghapus dsb) untuk mengikuti ujian secara tertib. Menurut Thurlow, Lazarus, Albus, dan Hodgson dalam Computer-based Testing: Practices and Considerations (2010).

\section{Google form}

Google form, adalah layanan online dari google untuk membuat formulir online, dan untuk mengumpulkan data, komentar, yang nantinya dapat disusun mengunakan spreadsheet. Disini penulis akan memberikan cara untuk membuat soal online, soal tersebut tidak hanya soal pilihan essay, tetapi juga dapat membuat soal pilihan ganda, yang nantinya dapat kita tampilkan ke halaman blog untuk kemudian dibagikan kepada 
peserta didik dan peserta didik dapat mengisinya hanya dengan membuka halaman blog tersebut dan mengisi jawaban.

Pengertian lain tentang google form adalah merupakan salah satu layanan yang diberikan google untuk kelola pendaftaran acara, jejak pendapat, membuat kuis, dan melakukan kuis secara online. Pada googleform terdapat tanggapan survei yang diolah menjadi sebuah grafik lingkaran. Yuke Yuliani Hamdani dan dkk (2017) Google form merupakan salah satu komponen layanan googledocs. Aplikasi ini sangat cocok untuk mahasiswa, guru, dosen, pegawai kantor dan professional yang senang membuat quiz, form dan survey online, fitur dari GoogleForm dapat dibagi ke orang-orang secara terbuka atau khusus kepada pemilik akun Google dengan pilihan aksesibilitas, seperti readonly (hanya dapat membaca) atau editable (dapat mengedit dokumen). memiliki akun universal Google, yaitu dengan mendaftar di

\section{METODELOGI PENELITIAN}

\section{Tempat dan Waktu Penelitian}

Penelitian ini akan dilaksanakan di SMP Negeri 38 Takengon di Jalan Pilar Wih Kiri Kampung Pilar Kecamatan Rusip Antara, Kabupaten Aceh Tengah. Waktu penelitian akan dilaksanakan pada tanggal 16 Juli 2020 s/d 30 September 2020.

\section{Subjek Penelitian}

Subjek dari penelitian ini adalah semua guru yang ada di SMP Negeri 38 Takengon. Oleh karena itu, diperlukan subjek yang memenuhi parameter yang dapat mengungkap hal di atas sehingga memungkinkan data dapat diperoleh.

\section{Objek Penelitian}

Objek dalam penelitian ini yaitu guru-guru yang terlibat dalam pembuatan soal ulangan online berbasis google form di SMP Negeri 38 Takengon.

\section{Tehnik Pengumpulan Data}

Pada penelitian ini menggunakan tehnik pengumpulan data wawancara, observasi, dan dokumentasi.

\section{Indikator Proses dan Indikator Keberhasilan}

Dari kegiatan pelatihan yang dilakukan di sekolah bertujuan agar mengetahui parameter, subjek penelitian yang dianggap memenuhi karakteristik yaitu $75 \%$ guru akan dapat membuat soal online berbasis goole form, $75 \%$ guru akan dapat melaksanakan ulangan online berbasis google form dan $75 \%$ siswa dapat melaksanakan ulangan online di SMP Negeri 38 Takengon.

\section{Petunjuk Penskoran:}

Lihat petunjuk penskoran pada pedoman observasi sikap piritual

$$
\text { Nilai }=\frac{\text { jumlahskor }}{\text { maks }(16)} \times 100 \%
$$

Adapaun kriteria indikator keberhasilan terhadap nilai kemampuan guru dalam melaksanakn pelatihan sebagai berikut:

$$
<50 \% \quad=\text { Kurang Sekali }
$$




$$
\begin{aligned}
& 51 \%-55 \%=\text { Kurang } \\
& 56 \%-65 \%=\text { Cukup } \\
& 66 \%-75 \%=\text { Baik } \\
& >75 \%=\text { Sangat baik }
\end{aligned}
$$

\section{HASIL PENELITIAN DAN PEMBAHASAN Deskripsi Kondisi Awal}

Penelitian ini merupakan Penelitian Tindakan Sekolah (PTS). PTS ini bertujuan untuk memperbaiki kinerja kepala sekolah untuk meningkatkan kemampuan pedagogik guru dalam membuat soal online berbasis google form dimana selama pendemik proses pembelajaran tidak dapat bertatap muka dengan siswa di kelas, sehingga guru kesulitan dalam melakukan evaluasi terhadap hasil belajar siswa. Pelaksanaan ulangan bertujuan agar guru dapat mengetahui kemajuan belajar dari siswa, untuk membuat soal online guru harus memahami google form terlebih dahulu, apa kelemahan dan kelebihan dari aplikasi tersebut. Hasil observasi yang dilkukan oleh kepala sekolah di SMP Negeri 38 Takengon 100\% guru belum dapat membuat soal online berbasis google form, pelaksanaan ulangan masih berjalan seperti biasa yaitu dengan menggunakan kertas dan pensil bahkan sebagian guru tidak melakukan ulangan. Utnuk menyelaraskan pembelajaran daring dan ulangan online kepala sekolah mengadakan pelatihan kepada guru untuk membuat soal online berbasis google form di SMP Negeri 38 Takengon.

Melalui pelatihan yang singkat diharapkan guru akan dapat membuat soal ulangan online berbasis goole form dan dapat menerapkannya untuk melakukan ulangan di sekolah, harapan kepala sekolah lebih dari $75 \%$ guru akan mampu membuat soal dan dapat menerapkannya pada saat Penilaian Tengah Semester (UTS), Penilaian Semester (PS) dan Penilaian Akhir Semester (UAS). Prosedur dalam penelitian ini menggunakan pendektatan Suharsimi Arikunto menggunakan metode siklus, penelitian terdiri dari dua siklus, hasil analisis siklus 1 akan menjadi perbandingan dengan hasil analisis siklus 2 .

\section{Kondisi Pra Siklus (Observasi Pendahuluan)}

Pandemik covid-19 sangat menjadi kendala untuk pelaksanaan proses pembelajaran dan evaluasi belajar siswa di sekolah, covid-19 menjadi permasalahan yang mendunia terhadap dunia pendidikan, khususnya di SMP Negeri 38 Takengon, proses pembelajaran normal sebelum pandemik dilaksanakan dengan tatap muka, dan ulangan dilakukan dengan berbasis kertas dan pensil, harapan kepala sekolah belajar dan proses pelaksanaan ulangan tetap berjalan meskipun dimasa pandemik covid-19. Kepala sekolah mengharapkan guru memiliki kemampuan pedagogik dalam membuat soal online serta memanfaatkan Information Tehcnology (IT) sesuai tuntutan pembelajaran abad-21.

Pada tanggal 20 Juli 2020, kepala sekolah melakukan sosialisasi kepada seluruh dewan guru di sekolah, bagaimana mengatasi permasalahan pembelajaran selama pandemik covid-19 dan evaluasi belajar siswa, dan bagaimana cara untuk mengatasi permasalahan tersebut, hasil sosialisasi bersama dewan guru sepakat bahwa melaksanakan pembelajaran menggunakan semi daring sebagaimana telah ditentukan sesuai edaran pemerintah kabupaten Aceh Tengah dan melaksanakan evaluasi belajar menggunakan google form berbasis online. Penelitian ini akan di laksanakan di SMP 
Negeri 38 Takengon sejak bulan Juli sampai dengan bulan September 2020, adapun objek dalam penelitian ini adalah semua guru di SMP Negeri 38 Takengon.

\section{Hasil observasi Pra Siklus}

Selain itu peneliti berharap akan ada peningkatan terhadap kemampuan pedagogik guru dalam membuat soal online berbaisi google form melalui pelatihan di SMP Negeri 38 Takengon.

Tabel Data guru yang telah mampu membuat soal online pra siklus

\begin{tabular}{|l|l|l|l|l|l|}
\hline No & Hasil (Angka) & Hasil (Huruf) & Arti Lambang & Jumlah Siswa & Persen(\%) \\
\hline 1. & $\mathbf{8 5}-\mathbf{1 0 0}$ & A & Sangat Baik & - & $\mathbf{0 \%}$ \\
\hline 2. & $\mathbf{7 5}-\mathbf{8 4}$ & B & Baik & - & $\mathbf{0 \%}$ \\
\hline 3. & $\mathbf{6 5}-\mathbf{7 4}$ & C & Cukup & - & $\mathbf{0 \%}$ \\
\hline 4. & $\mathbf{5 5}-\mathbf{6 4}$ & D & Kurang & - & $\mathbf{0 \%}$ \\
\hline 5. & $<54$ & E & Sangat Kurang & $\mathbf{1 6}$ & $\mathbf{1 0 0 \%}$ \\
\hline & & Jumlah & & 16 & $100 \%$ \\
\hline
\end{tabular}

Sumber : hasil tabulasi Agustus 2020

Hasil analisis yang digambarkan dalam bentuk tabel diketahui bahwa jumlah guru yang mendapat nilai A (Sangat Baik) sejumlah $0 \%$ atau tidak ada, yang mendapat nilai B (Baik) sebanyak $0 \%$ atau sebanyak $0 \%$ atau tidak ada dan yang mendapat nilai $\mathrm{C}$ (cukup) sebanyak $0 \%$ dan yang mendapat nilai D (kurang) $0 \%$. Serta yang mendapat nilai E (Sangat Kurang) sebanyak $100 \%$, sebanyak 16 guru.

Dari tabel di atas terlihat tidak ada satu guru yang telah mampu membuat soal online berbasis google form di sekolah, meskipun ada sebagian guru yang telah mengetahui tentang aplikasi google form, namun belum dapat untuk mengaplikasikannya sebagai media ulangan. Hal tersebut terjadi karena selama ini guru di SMP Negeri 38 Takengon belum pernah mengembangkan atau mengikuti pelatihan memnfatkan aplikasi IT sebagai alat ukur evaluasi hasil belajar siswa.

Tabel Data guru yang telah melaksanakan ulangan online pra siklus

\begin{tabular}{|c|l|l|l|l|l|}
\hline No & Hasil (Angka) & Hasil (Huruf) & Arti Lambang & Jumlah Siswa & Persen(\%) \\
\hline 1. & $\mathbf{8 5}-\mathbf{1 0 0}$ & A & Sangat Baik & - & $0 \%$ \\
\hline 2. & $75-84$ & B & Baik & - & $0 \%$ \\
\hline 3. & $65-74$ & C & Cukup & - & $0 \%$ \\
\hline 4. & $55-64$ & D & Kurang & - & $0 \%$ \\
\hline 5. & $<54$ & E & Sangat Kurang & 16 & $100 \%$ \\
\hline & Jumlah & & 16 & $\mathbf{1 0 0 \%}$ \\
\hline
\end{tabular}

\section{Sumber : hasil tabulasi Agustus 2020}

Hasil analisis yang digambarkan dalam bentuk tabel diketahui bahwa jumlah guru yang telah melaksanakan ulangan online berbasis goole form dengan nilai A (Sangat Baik) sejumlah $0 \%$ atau tidak ada, yang mendapat nilai B (Baik) sebanyak 0\% atau sebanyak $0 \%$ atau tidak ada dan yang mendapat nilai $\mathrm{C}$ (cukup) sebanyak $0 \%$ dan yang mendapat nilai D (kurang) $0 \%$. Serta yang mendapat nilai E (Sangat Kurang) sebanyak $100 \%$, sebanyak 16 guru.

Dari data di atas terlihat bahwa belum ada satu guru yang telah melaksanakan ulangan online berbaisis google form di sekolah.

Dari hasil wawancara yang telah dilaksanakan serta pretest belum ada guru yang mampu membuat soal online berbasis google form dan belum ada guru yang telah 
menerapkan ulangan online berbasis google form. Data ketuntasan guru membuat soal ulangan online dan melaksanakan ulangan online berbasis google form di SMP Negeri 38 Takengon, pada kondisi awal dapat diketahui pada tabel dibawah ini.

Tabel Ketuntasan guru dalam membuat soal dan melaksanakan ulangan online pra siklus

\begin{tabular}{|l|l|l|l|}
\hline \multirow{2}{*}{ No } & \multirow{2}{*}{ Ketuntasan Belajar } & \multicolumn{2}{|l|}{ Jumlah guru } \\
\cline { 3 - 4 } & & Pra Siklus \\
\cline { 3 - 4 } & & Jumlah & Persen \\
\hline $\mathbf{1 .}$ & Tuntas & - & $0 \%$ \\
\hline $\mathbf{2 .}$ & Belum Tuntas & 16 & $100 \%$ \\
\hline \multicolumn{5}{|l}{ Jumlah } & 16 & $100 \%$ \\
\hline
\end{tabular}

Sumber : Hasil Tabulasi data Agustus 2020

Berdasarkan data pada tabel diatas, diketahui bahwa guru yang mencapai ketuntasan belajar dengan parameter 75 adalah tidak ada atau (0\%). Dengan demikian jumlah guru yang belum mencapai ketuntasan dalam membuat soal online berbasis google form dan melaksanakn ulangan online berbasis goole form adalah $0 \%$. Dari hasil pengamatan data tersebut, maka guru harus diberi pelatihan sebagaimana tujuan kesepakatan guru dan kepala sekolah pada saat sosialisasi pelaksanaan ulangan akan dilaksanakan online berbasis google form dengan menggunakan android ataupun laptop.

\section{Deskripsi Pelaksanaan Siklus I}

Dari analisis pra siklus di atas menunjukan bahwa belum ada guru yang mampu membuat soal online berbasis goole form dan melaksanakan ulangan online berbasis google di SMP Negeri 38 Takengon.

a. Perencanaan

Pada tahap perencanaan siklus 1 peneliti menyusun materi atau power point untuk bahan pemateri pada pelalatihan yang akan dilaksanakan di SMP Negeri 38 Takengon. Tujuan dari pelatihan ini adalah untuk meningkatkan kemampuan guru dalam membuat soal online berbasis goole form dan melaksanakan ulangan online berbasis goole form.

b. Pelaksanaan

Kegiatan pelatihan dilaksanakan pada hari senin taggal, 7 Agustus 2020, jam 8.40 WIB s/d 1.00 WIB di SMP Negeri 38 Takengon, pelatihan yang di maksud adalah pembelajaran langsung. Sebelum pelatihan dipastikan guru memiliki email serta android maupun lapotop. Login Email, cari Google Drive, pilih Google Formulir. Buat Judul dan deskripsi di halaman Google formulir sesuai dengan mata pelajaran yang akan diujikan. Jangan lupa cantumkan biodata siswa, seperti: Nama Siswa, Jenis Kelamin dan Kelas. Observasi

Hasil pelaksanaan pelatihan pada siklus I, peneliti melakukan pengamatan, diperlukan untuk mengetahui secara detail partisipasi guru dalam mengikuti pelatihan membuat soal online berbasis goole form. Dari hasil pengamatan maka diketahui peningkatan kemampuan guru dalam membuat soal ulangan online berbasisi goole form adalah dengan kriteria sangat baik, sebanyak 1 orang guru $(6,25 \%)$, baik 0 orang guru $(0 \%)$, cukup 4 orang guru $(25 \%)$, kurang 6 orang guru $(37,5 \%)$ dan sangat kurang 5 orang guru $(31,25 \%)$. Dari data tersebut di atas pada siklus 1 , kemampuan guru dalam membuat soal online bebrbasis google form telah mengalami perubahan. 
c. Refleksi

Berdasarkan hasil analisis pelaksanaan pelatihan terhadap guru dalam mebuat soal ulangan online berbasis goole form telah terjadi peningkatan namun masih ada kendala di sebagaian kecil pada materi adalah :

1. Secara keseluruhan guru sudah mampu mengaplikasikan google form menggunakan email yang dimiliki dan membuat soal ulangan online berbasis goole form.

2. Semua guru telah dapat mengujicobakan soal yang di buat untuk melaksanakan ulangan online berbasis goole form.

3. Sebagian guru belum dapat membuat soal online berbasis google form karena pada saat pelatihan tidak hadir, tidak memiliki android, dan tidak terkoneksi dengan jaringan internet.

4. Guru masih gagal untuk membuat pengaturan pada aplikasi agar siswa tidak dapat melakukan kecurangan pada saat ulangan berlangsung, missal siswa akan membuka aplikasi google untuk mencari jawaban, sementara pada aplikasi dapat di atur jika siswa keluar dari soal, maka siswa akan gagal masuk kembali pada laman soal.

Berdasarkan hasil observasi dan refleksi berikut perbandingan peningkatan kemampuan guru dalam membuat soal ulangan online berbasis google form melalui pelatihan dan pembelajaran langsung. Berikut tabel perbandingan perubahan kemampuan guru dalam membuat soal online sebelum pelatihan dengan sesudah pelatihan.

Tabel Perubahan kemampuan guru dalam membuat soal online Siklus I

\begin{tabular}{|c|c|c|c|c|}
\hline No & Hasil (Angka) & Arti Lambang & Jumlah Peserta didik & Persen(\%) \\
\hline 1. & $\mathbf{8 5}-\mathbf{1 0 0}$ & Sangat Baik & $\mathbf{1}$ & $\mathbf{6 , 2 5 \%}$ \\
\hline 2. & $\mathbf{7 5 - 8 4}$ & Baik & - & $\mathbf{0 \%}$ \\
\hline 3. & $\mathbf{6 5}-\mathbf{7 4}$ & Cukup & 13 & $\mathbf{8 1 , 2 5 \%}$ \\
\hline 4. & $\mathbf{5 5 - 6 4}$ & Kurang & - & $\mathbf{0 \%}$ \\
\hline 5. & $<54$ & Sangat Kurang & $\mathbf{2}$ & $\mathbf{1 2 , 5 \%}$ \\
\hline & & & 16 & $\mathbf{1 0 0 \%}$ \\
\hline
\end{tabular}

\section{Sumber : hasil tabulasi Agustus 2020}

Hasil analisis yang digambarkan dalam bentuk tabel diketahui bahwa jumlah guru yang telah mampu membuat soal ulangan online berbasis google form dengan nilai A (Sangat Baik) sejumlah 6,25\% atau 1 orang guru, yang mendapat nilai B (Baik) sebanyak $0 \%$ atau sebanyak $0 \%$ atau tidak ada dan yang mendapat nilai $\mathrm{C}$ (cukup) sebanyak $81,25 \%$ atau sebanyak 13 orang guru, dan yang mendapat nilai D (kurang) $0 \%$ atau sebanyak 0 orang guru. Serta yang mendapat nilai E (Sangat Kurang) sebanyak $12,5 \%$, sebanyak 12 orang guru. Dari data di atas terlihat bahwa kemampuan guru dalam membuat soal online berbasis google form sudah mengalami peningkatan di bandingkan dengan pra siklus.

\section{Deskripsi pada Siklus II}

Dari hasil analisis siklus I diatas menunjukan bahwa peningkatan kemampuan guru dalam membuat soal ulangan online berbasis google form melalui pelatihan dalam pembelajaran langsung mengalami ada peningkatan, hasil observasi terhadap guru dalam membuat soal ulangan online masih ada beberapa kelemahan sebagian guru 
belum mampu mengatur waktu siswa dalam menjawab soal, mendesain tampilan soal pada goggle form, tidak dapat melihat hasil belajar siswa setelah selesai ulangan online berbasis google form. Sehingga penelitian ini masih dilanjutkan pada siklus II.

a. Perencanaan

Pada tahap awal perencanaan peneliti masih melanjutkan materi yang telah disiapkan di awal pelatihan, pada pertemuan ini peneliti berusaha meningkatkan kemampuan guru dalam membuat soal ulangan online berbasis google form dan mampu untuk melaksanakan ulangan online berbasis goole form melalui pelatihan dan pembelajaran langsung.

b. Pelaksanaan

Penelitian dilakukan pada hari senin tanggal, 24 Agustus 2020, jam 8.30 WIB s/d 12.30 WIB di kantor dewan guru SMP Negeri 38 Takengon, penelitian ini menggunakan pelatihan pembelajaran langsung bersama guru.

c. Observasi

Dari hasil pelaksaan, peneliti perlu untuk melakukan pengamatan untuk mengetahui secara detail partsipasi aktif dalam pelatihan terhadap guru di SMP Negeri 38 Takengon. Dari pelaksanaan pelatihan melalui pembelajaran langsung membuat soal online berbasis google form, peneliti berharap akan terjadi peningkatan kemampuan guru dalam membuat soal ulangan berbasis google form terhadap guru melalui pelatihan luring, berikut table analisis.

Tabel Analisis kemampuan guru dalam membuat soal online berbasis google form melalui pelatihan Siklus II

\begin{tabular}{|c|l|l|l|l|}
\hline No & Hasil (Angka) & Arti Lambang & Jumlah Peserta didik & Persen(\%) \\
\hline 1. & $\mathbf{8 5}-\mathbf{1 0 0}$ & Sangat Baik & $\mathbf{8}$ & $\mathbf{5 0 \%}$ \\
\hline 2. & $\mathbf{7 5 - 8 4}$ & Baik & 4 & $\mathbf{2 5 \%}$ \\
\hline 3. & $\mathbf{6 5}-\mathbf{7 4}$ & Cukup & - & $\mathbf{0 \%}$ \\
\hline 4. & $\mathbf{5 5}-\mathbf{6 4}$ & Kurang & $\mathbf{3}$ & $\mathbf{1 8 , 7 5 \%}$ \\
\hline 5. & $<54$ & Sangat Kurang & $\mathbf{4}$ & $\mathbf{2 5 \%}$ \\
\hline & & $\mathbf{1 6}$ & $\mathbf{1 0 0 \%}$ \\
\hline
\end{tabular}

\section{Sumber : hasil tabulasi Agustus 2020}

Berdasarkan tabel rekapitulasi ketercapaian kemampuan guru dalam membuat soal online dan penerapanya dengan kriteria sangat baik sebanyak 8 orang guru (50\%), baik sebanyak 4 orang guru (25\%), cukup baik 0 orang guru ( $0 \%)$, kurang baik 3 orang guru $(18,75 \%)$, dan sangat kurang sebanyak 1 orang guru $(6,25 \%)$. Peningkatan kemampuan guru dalam membuat soal online dan penerapanya untuk melaksanakan ulangan kepada siswa terjadi peningkatan, dengan melalui pelatihan pembelajaran langsung di SMP Negeri 38 Takengon sehingga penelitian diakhiri pada pada siklus II.

\section{Pembahasan}

Pelaksanaan pelatihan dilaksanakan di SMP Negeri 38 Takengon, guru sangat antusias mengikuti pelatihan. Hasil kegiatan pelatihan menunjukan bahwa guru memiliki kemampuan dan kemauan yang luar biasa sehingga hasil pelatihan terjadi peningkatan nilai pada indikator disetiap siklusnya. Peningkatan mulai dari kemampuan guru dalam membuat soal ulangan online berbasis google form serta guru dapat menerapankan ualangan online berbasis google form. Pada penelitian ini dapat 
dinyatakan berhasil karena telah mencapai target. Berikut peningkatan capaian aspek setiap siklusnya dapat dilihat pada grafik berikut ini.

\section{Grafik. Perbandingan peningkatan kemampaun pedagogik guru antara Pra} Siklus, Siklus I dan Siklus II

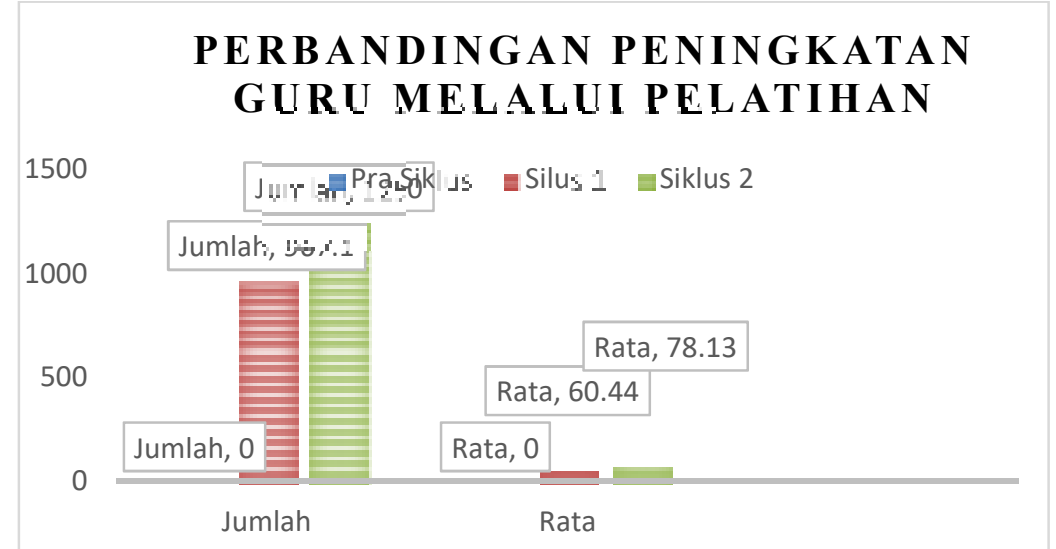

Gambar. Grafik peningkatan capaian ketuntasan setiap siklusnya

Dari grafik di atas menunjukan bahwa, peningkatan kemampuan guru dalam membuat soal online berbasis google form telah mengalami peningkatan, sebelum diadakan pelatihan tahap pra siklus belum ada guru yang mampu membuat soal online, pada pra siklus ke siklus 1 terjadi peningkatan dengan nilai rata-rata sebesar 60,44, hal ini terlihat adanya peningkatan kemampuan pedagogik guru dalam membuat soal online sangat di pengauhi oleh adanya program pelatihan mini yang dilaksanakna di SMP Negeri 38 Takengon.

Adapun peningkatan kemampuan guru dalam membuat soal ulangan online berbasis google form adalah pada pra siklus guru belum memiliki kemampuan dalam membuat soal online atau setara dengan $0 \%$ atau 0 orang guru, pada siklus 1 guru telah mengikuti pelatihan dan terjadi peningkatan dengan rata-rata sebesar 60,44, sementara pada siklus 2 nilai rata-rata yang diperoleh oleh guru melalui pelatihan adalah 78,13 , sehingga terjadi peningkatan kemampuan guru dalam membuat soal ulangan online dari siklus 1 ke siklus 2 adalah 17,69\%. Jadi berdasarkan paparan grafik diatas semua terjadi peningkatan pada setiap siklusnya dan mencapai aspek capaian yang telah ditentukan diawal penelitian.

Berdasarkan hasil pengamatan peneliti pada saat proses pelatihan ada dua orang guru yang tidak dapat mengikuti pelatihan dikarenakan dalam keadaan kurang sehat, dan ada hal lain yang harus diselesaikan, sehingga guru tersebut masih belum mampu dalam membuat soal online dan menerapkan ulangan online.

Setelah memberikan materi atau pelatihan kepada guru, peneliti langsung mengujicobakan kemampuan guru, dengan membagikan soal ulangan online yang telah mereka selesaikan, dengan membagikan soal tersebut kepada guru atau teman sejawat yang telah mengikuti pelatihan sebagai bukti hasil dari pelatihan. Namun setelah diamati oleh peneliti, guru yang telah mengikuti pelatihan dapat dikatakan berhasil untuk melaksanakan ulangan online berbasis google form dengan menggunakan android maupun komputer.

Kendala yang dihadapi oleh guru pada saat membuat soal online berbasis google form adalah masih terdapat sebagian guru tidak memiliki email yang aktif, tidak 
semua guru memiliki android atau laptop, dan yang terpenting adalah paket data atau kuota internet, namun masih terdapat sebagian guru tidak memiliki paket, akan tetapi pada saat pelatihan masih bisa membagikan hotsport wi-fi dengan teman sejawat.

Kendala yang dihadapi oleh siswa pada saat melaksanakan ulangan online berbasis google form adalah sama halnya seperti kendala yang dihadapi oleh guru, yaitu tidak memiliki email yang aktif, belum semua siswa memiliki android, dan paket data internet, sehingga hal tersebut dapat menghambat pelaksanaan ulangan online bagi siswa di SMP Negeri 38 Takengon. Untuk mengatasi permasalahan kurangnya android yang dimiliki oleh siswa dalam melaksanakan ulangan online ialah guru dapat meminjamkan android pribadinya ke siswa, dan siswa dapat menggunkan tablet yang dimiliki oleh sekolah.

Selain itu listrik merupakan kunci utama untuk melakukan pembuatan soal online dan ulangan online, namun yang kami hadapi pada saat ini listrik di daerah sekolah kami yaitu Kecamatan Rusip Antara sering padam sehingga jika listrik padam maka jaringan internet juga terputus. Selain itu listrik menjadi sumber energi terhadap pengisian daya komputer, laptop dan android.

Solusi yang kami ambil dalam mengatasi padamnya listrik di wilayah kami yaitu di Kecamatan Rusip Antara, sebelum merencanakan pelaksanaan ulangan kami meberitahukan kepada pihak PLN, agar kondusip dalam memantau aliran listrik ke wilayah SMP Negeri 38 Takengon, karena siswa akan melaksanakan ulangan online di sekolah.

\section{Kesimpulan}

Berdasarkan hasil analisa data dan pembahasan dapat disimpulkan bahwa malaui pelatihan terdapat peningkatan yang signifikan terhadap kemampuan pedagogik guru dalam membuat soal ulangan online berbasis google form di SMP Negeri 38 Takengon, selain itu pelaksanaan ulangan online berbasis google form dapat diterapkan terhadap siswa dengan menggunakan android melaui WhatsApp dimasa pandemik covid-19 dan paska pandemik covid-19.

\section{DAFTAR PUSTAKA}

Anggraini., L. 2007, Sistem Ujian Online dan Penilaian siswa berbasis web pada SMA PGRI 109 Tangerang, Skripsi, Fakultas Teknik, Universitas Mercu Buana, Tangerang.

Arikunto, Suharsimi (Ed). 2012. Dasar-Dasar Evaluasi Pendidikan. Jakarta: Bumi Aksara.

Depdiknas .2006. Permendiknas No 22 Tahun 2006 Tentang Standar Isi. Jakarta : Depdiknas.

Nana Sudjana 2010. Dasar-dasar Proses Belajar, Sinar Baru Bandung

Purwanto. 2011. Evaluasi Hasil Belajar. Yogyakarta: Pustaka Pelajar

Suyono dan Hariyanto, 2011.Belajar dan Pembelajaran. Bandung: PT Remaja Rosdakarya Offset.

Yuke Yuliani Hamdani dan dkk(2017). G Suite. Bandung: Lembaga Sistem Informasi. 